\title{
PENINGKATAN HASIL BELAJAR PADA MATERI PETA DENGAN MODEL PEMBELAJARAN NUMBERED HEADS TOGETHER SISWA KELAS VII-B DI SMPN 1 SUMBERPUCUNG KABUPATEN MALANG
}

\author{
Arisa Putra \\ Universitas Kanjuruhan Malang \\ Email: arisaputra@gmail.com
}

\begin{abstract}
Abstrak
Berdasarkan observasi yang dilakukan di SMP Negeri 1 Sumberpucung Kelas VII-B, diketahui bahwa pelaksanaan pembelajaran Geografi sebagian besar masih menggunakan metode konvensional. Siswa tidak dibebaskan untuk belajar sesuai dengan minatnya sehingga belajar menjadi membosankan kebanyakan siswa hanya duduk, diam, mendengarkan, mencatat serta sibuk dengan pekerjaannya yang lain. Hal tersebut sangat berpengaruh pada hasil belajar siswa. Oleh karena itu, Numbered-Heads Togther mengajak siswa untuk menemukan gaya belajarnya dan mendapatkan pengalaman baru dalam belajar sehingga akan terjadi interaksi antar siswa. Penelitian ini menggunakan Penelitian Tindakan Kelas (PTK) yang dilaksanakan dalam 2 siklus. Siklus I membahas mengenai materi tentang peta umum yaitu peta yang berisi berbagai kenampakan secara umum misalnya peta dunia. Sedangkan siklus II membahas materi Atlas dan globe. Penelitian ini menggunakan pendekatan kualitatif dengan jenis Penelitian Tindakan Kelas (PTK) yang terdiri dari 2 siklus. Setiap siklus terdiri dari perencanaan, pelaksanaan, observasi dan refleksi. Tujuan penelitian ini yaitu untuk Mendeskripsikan peningkatan hasil belajar pada materi peta dengan model pembelajaran numbered Heads Together (NHT) Siswa kelas VII- B di SMPN 1 Sumberpucung Kabupaten Malang Penelitian dilaksanakan pada semester genap tahun pelajaran 2013/2014 di kelas VII-B SMP Negeri 1 Sumberpucung. Subjek dalam penelitian ini berjumlah 38 siswa yang terdiri dari 18 siswa laki-laki dan 20 siswa perempuan. Dalam hal ini, peneliti menerapkan model pembelajaran Numbered-Heads Together untuk meningkatkan hasil belajar siswa kelas VII-B SMP Negeri 1 Sumberpucung. Model pembelajaran Numbered-Heads Together terdiri dari 4 tahap dengan langkah-langkah sebagai berikut ; 1.Tahap penomoran,2.Tahap pengajuan Pertayaan,3.Tahap Berfikir,4. Berdasarkan penelitian ini dapat disimpulkan bahwa penerapan pembelajaran dengan menggunakan model pembelajaran Numbered-Heads Together dapat meningkatkan hasil belajar pada mata pelajaran Geografi siswa kelas VII-B SMP Negeri 1 Sumberpucung
\end{abstract}

Kata Kunci: Numbered Heads Together, hasil belajar.

\section{PENDAHULUAN}

Masalah yang sering dihadapi siswa adalah tidak pede di kelas. Dengan kata lain, mereka tidak bisa menjadi anak yang aktif dan berinteraksi dengan teman-teman dengan baik. Siswa tersebut cenderung merasa malu dan gugup ketika harus ke depan kelas. Ini dapat mempengaruhi nilai hasil belajar nya. Pada dasarnya Pendidikan itu sendiri adalah proses alih informasi dan nilai-nilai yang ada selama proses ini terjadi, pengalaman dan penalaran pengambilan keputusan seseorang akan bertambah baik. Hasil akhir suatu proses pendidikan adalah terbentuknya seorang yang mampu berdiri sendiri, bekerja dan tak pernah berhenti belajar dan mengembangkan apa yang telah diperoleh.

Pembelajaran merupakan proses kegiatan belajar mengajar dengan tujuan menyalurkan pengetahuan dari guru kepada siswa. Keberhasilan dari 
pembelajaran sangatlah di pengaruhi oleh sistem dari pembelajaran itu sendiri. Salah satu sistem pembelajaran yang baik adalah yang bisa membuat siswa trampil aktif dan tidak membosankan baik di kelas maupun diluar kelas. Mengajar itu sendiri bukanlah hanya menuangkan bahan pelajaran kedalam otak siswa atau menyampaikan kebudayaan bangsa kepada anak-anak namun mengajar yang baik dan efektif sangat kompleks dan bergantung pada interaksi dari berbagai faktor misalnya dari gurunya sendiri sebagai pengajar maupun dari siswa sebagai subjek belajar.

Keahlian mengajar tidak mungkin tercapai tanpa suatu syarat serta hasrat yang kuat kemudian tumbuh dan berkembang personal dan propesional, maka dari itu proses belajar mengajar seorang guru harus memiliki strategi agar siswa dapat belajar efektif dan efesien serta mengena pada tujuan yang diharapkan. Salah satu cara untuk memiliki strategi itu ialah dengan mengunakan pola sebagai model pembelajaran yang sesuai dengan kondisi anak serta kapasitas kelas yang ada di sekolah. Pola atau model pembelajaran dikelas merupakan objek penting yang berpengaruh terhadap diri siswa hal ini merupakan salah satu faktor utama yang menyebabkan siswa kurang bersemangat dalam belajar. Suasana kelas yang dapat mendukung semangat belajar siswa sangat menguntungkan bagi siswa dalam mencapai efektivitas belajar disekolah, dimana suasana belajar yang baik dapat tercapai dengan adanya penyusunan model pembelajaran yang baik pula sedangkan penyusunan model pembelajaran yang tidak tersusun secara baik banyak menimbulkan suasana belajar yang kurang baik. Berdasarkan analisis konseptual dan kondisi pendidikan geografi di tingkat pendidikan, ternyata masih banyak guru yang belum memiliki kemampuan dan keterampilan yang memadai dalam memilih, serta mengunakan berbagai metode pembelajaran yang mampu mengembangkan iklim pembelajaran yang kondusif bagi siswa untuk belajar, banyak diantar guru yang tidak memiliki kurikulum tertulis yang merupakan pedoman dasar dalam pemilihan metode pembelajaran. Disamping itu, tidak sedikit siswa mengalami kesulitan dalam mengikuti pelajaran di karenakan metode pembelajaran yang di pilih dan di gunakan oleh guru di rasakan kurang tepat. Dengan demikian proses belajar mengajar (PBM) akan berlangsung secara kaku, sehingga kurang mendukung pengembangan pengetahuan, sikap, moral, dan keterampilan siswa.

Pemilihan model dan metode pembelajaran yang sesuai dengan tujuan kurikulum dan potensi siswa merupakan kemampuan dan keterampilan dasar yang harus di miliki oleh seorang guru. Hal ini di dasari oleh asumsi, bahwa ketepatan guru dalam memilih model dan metode pembelajaran akan berpengaruh terhadap keberhasilan dan hasil belajar siswa, karena model dan metode pembelajaran yang digunakan oleh guru berpengaruh terhadap kualitas PBM yang dilakukan.

Peranan guru dalam pembelajaran adalah mediator dan fasilitator dalam pembentukan pengetahuan dan pemahaman siswa. Agar siswa merasa bahwa pelajaran geografi itu tidak sulit yang dibayangkan, maka sebaiknya guru menggunakan metode yang membuat siswa banyak beraktivitas sesuai dengan pendekatan yang tepat 
tertentu, kemudian siswa yang nomornya sesuai mengacungkan tangannya dan mencoba untuk menjawab pertanyaan untuk seluruh kelas.

\section{METODE PENELITIAN}

Pendekatan yang digunakan dalam penelitian ini adalah pendekatan kualitatif, yaitu penelitian yang dinyatakan dalam bentuk verbal dan dianalisis tanpa menggunakan statistik. Sedangkan jenis penelitian yang dilaksanakan adalah penelitian tindakan kelas (PTK).

PTK adalah proses investigasi terkendali untuk menemukan dan memecahkan masalah di kelas, proses pemecahan masalah tersebut dilakukan secara bersiklus atau berputar dengan tujuan untuk meningkatkan kualitas proses dan hasil belajar di kelas. Dalam bab III memaparkan tentang: a) Jenis penelitian, b) kehadiran peneliti, c) Lokasi penelitian, d) subjek penelitian, e) instrument penelitian, f) Prosudur pengumpulaan data, g) Analisis data, h) Pemeriksaan keabsahan data, i) Tahaptahap penelitian

Adapun lokasi yang dijadikan sebagai tempat Penelitian ini adalah SMP N 1 Sumberpucung VIIB Kabupaten Malang. Instrumen yang digunakan dalam penelitian ini yaitu: soal tes, pedoman observasi keterlaksanaan pembelajara, dsn catatan lapangan.

\section{HASIL DAN PEMBAHASAN}

Dari wawancara penelitian dengan guru bidang studi Geografi, diketahui bahwa siswa kelas VIIB SMP Negeri 1 Sumberpucung sulit untuk memahami pelajaran Geografi walaupun dijelaskan secara berulang-ulang yang disertai dengan penggunaan media. Pada waktu proses pelajaran siswa sebagian ramai dikarenakan kurangnya minat belajar, hal ini mengakibatkan hasil belajar siswa kurang dalam mata pelajaran. Hal ini dapat dilihat dari hasil ulangan harian yang rata-rata hanya 63,02 dan nilai ketuntasan belajarnya hanya mencapai $60 \%$.

Melalui hasil observasi yang dilakukan pada tanggal 18 Januari 2014 peneliti mendapat data yaitu jadwal mengajar hanya pada hari Senin-Selasa tanggal 20 Januari 2014 di kelas VIIB dengan jumlah siswa 38 orang. Pada pertemuan pertama ketika peneliti memperkenalkan diri kepada siswa sebagai guru pengajar untuk mata pelajaran Geografi menggantikan guru bidang studi, siswa tampak sedikit ramai. Peneliti melakukan observasi awal ini untuk mengetahui kondisi dan motivasi siswa dalam belajar Geografi.

Dari pengamatan pada saat pembelajaran berlangsung, diperoleh data bahwa siswa jarang sekali bertanya, mereka diam walaupun ada beberapa siswa yang membuat keramaian. Kebanyakan siswa mendengarkan penjelasan guru, karena memang guru bidang studi Geografi menggunakan metode ceramah. Dan ketika disuruh bertanya siswa hanya diam dan kelihatan takut. Selain faktor tersebut faktor lain juga perlu dituliskan bahwa siswa sering tidak mencatat dan malas mengerjakan tugas yang diberikan.

Sebelum penelitian dilaksanakan terlebih dahulu peneliti mengadakan obesevasi awal yaitu dengan melakukan wawancara dengan guru bidang studi Geografi di SMP Negeri 1 Sumberpucung dengan tujuan untuk mengumpulkan data-data berupa nilai 
ulangan siswa. Nilai ulangan siswa tersebut sebagai nilai awal aatu refleksi awal sebelum peneliti menerapkan pembelajaran koopertif Model NHT pada pokok bahasan Peta, Atlas, dan Globe. Berdasarkan wawancara dengan guru bidang studi Geografi, peneliti memperoleh data bahwa nilai rata-rata dari 38 orang siswa kelas VIIB pada SMP Negeri 1 Sumberpucung yang tuntas belajar berjumlah 25 siswa atau ketuntasan dalam bentuk persen (\%) adalah 60 sedangkan nilai rata-rata adalah 63,02. Ketuntasan belajar ini juga akan digunakan sebagai bahan pertimbangan dan informasi terhadap ketuntasan belajar akhir pembelajaran pada siklus I, dan II.

Setelah diadakan tindakan pada setiap siklus, maka data yang diperoleh adalah pada siklus I hasil frekuensi ketercapaian skenario pembelajaran yaitu $64,52 \%$, frekuensi kegiatan siswa $64,28 \%$, dan ketuntasan belajar siswa $62,58 \%$. Pada siklus I ini ketuntasan belajar siswa belum mencapai SKM yang sudah ditetapkan di sekolah yaitu 75. Sehingga perlu diadakan perbaikan pada siklus II. Pada siklus II data-data yang diperoleh dari frekuensi ketercapaian skenario pembelajaran $80,76 \%$. Frekuensi kegiatan siswa $100 \%$, dan ketuntasan belajar siswa $85,71 \%$.

Hal ini pula dapat dilihat melalui hasil penelitian yang telah dilkukan oleh peneliti-peneliti sebelumnya mengenai metode pembelajaran koopertif Learning Model NHT untuk meningkatkan hasil belajar siswa.
Tabel 1. Hasil Keseluruhan Siklus I dan Siklus II

\begin{tabular}{clcc}
\hline No & Penilaian & $\begin{array}{c}\text { Siklu } \\
\text { I\% }\end{array}$ & $\begin{array}{c}\text { Siklus } \\
\text { II\% }\end{array}$ \\
\hline 1 & $\begin{array}{l}\text { Ketercapaian } \\
\text { Skenario } \\
\text { Pembelajaran }\end{array}$ & $64,52 \%$ & $80,76 \%$ \\
2 & $\begin{array}{l}\text { Kegiatan } \\
\text { Siswa }\end{array}$ & $64,28 \%$ & $100 \%$ \\
& (Diskusi) & & \\
3 & Hasil Belajar & $62,58 \%$ & $88,71 \%$ \\
\hline
\end{tabular}

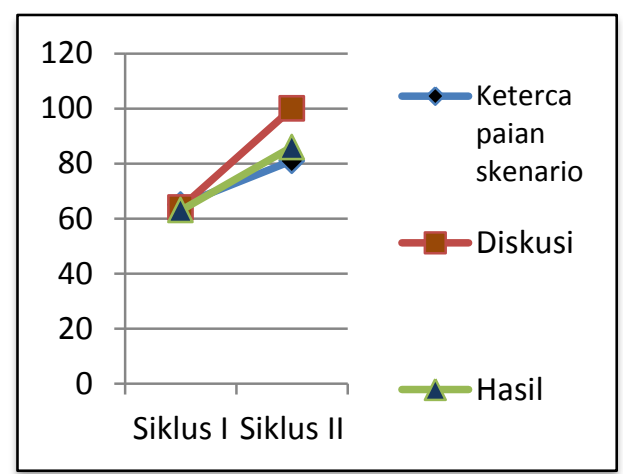

Gambar 1. Grafik Hasil Keseluruhan Dari Siklus I dan II

\section{KESIMPULAN}

Berdasarkan paparan data dan hasil pembahasan, maka dapat disimpulkan beberapa hal berikut: Model Pembelajaran Numbered Head's Together (NHT) dapat meningkatkan hasil belajar siswa Geografi pada pokok bahasan Peta, Atlas, dan Globe kelas VII B SMPN 1 Sumberpucung Kabupaten Malang. Hal ini jelas terlihat dari nilai ketuntasan belajar pada siklus I adalah $62,58 \%$ dan nilai ketuntasan belajar pada siklus II adalah $85,71 \%$.

\section{DAFTAR RUJUKAN}

Arikunto, Suharsimi. 2002. Prosedur Penelitian Suatu Pendekatan Praktek. Jakarta: PT Asdi Mahastya Aqib, Zainal. 2006. 
Penelitian Tindakan Kelas. Bandung: $\mathrm{Cv}$ Yrama widya

Djunady, Ghony. 2008. Penelitian Tindakan Kelas. Malang: Universitas Islam Negeri Malang.

Dimyanti, Mudjiono. 2006. Belajar Dan Pembelajaran. Jakarta: Rieneka Cipta

Budiningsih, Asri. 2004. Belajar dan Pembelajaran. Yokyakarta: Rineka Cipta.

Gintings, Abdorrakhman.2008. Esensi Praktis Belajar Pembelajaran. Yogyakarta : Universitas Negeri Yogyakarta.

Husnul, chotimah dkk. 2009. Strategi Strategi Pembelajaran. Malang: Surya Pena Gemilang

Isjoni. 2009. Pembelajaran Kooperatife, Yogyakarta: Pustaka Pelajar.
Kasbolah, kasihani. 1998. Penelitian Tindakan Kelas. Filsafat. Malang: FKIP Universitas Kanjuruhan Malang.

Maftuhah, Aulia. 2009. Upaya Meningkatkan Hasil Belajar Dan Motivasi Belajar Siswa Dengan Implementasi Model Pembelajaran kooperatif Tipe Combination Methode Of STAD And TGT. Malang: Skripsi Tidak Diterbitkan (diktat).

Moleong, 2006. Metodologi Penelitian Kualitatif. Bandung: PT Remaja Rosdakarya.

Slameto 1991. Belajar dan Faktor-faktor yang mempengaruhinya, Jakarta: Rieneka Cipta.

Slavin, R.E. 1995. Cooperative Learning: Theory, Resarch, and Practice Scond editi: Massaachussetts: Allyn and Boston Publisher. 